\title{
Mimicking Spray Drying by Drying of Single Droplets Deposited on a Flat Surface
}

\author{
Jimmy Perdana $\cdot$ Martijn B. Fox $\cdot$ \\ Maarten A. I. Schutyser • Remko M. Boom
}

Received: 18 August 2011 / Accepted: 20 December 2011 / Published online: 10 January 2012

(C) The Author(s) 2012. This article is published with open access at Springerlink.com

\begin{abstract}
The inactivation of bioactive ingredients during spray drying is often matrix specific. Therefore, the design of new processes or the optimisation of existing spray drying processes is usually highly product specific and requires numerous experiments. Rapid experimentation methods that facilitate fast data generation are therefore desired. A novel method for drying single droplets to mimic spray drying is proposed. The approach involves droplet deposition on a hydrophobic flat surface followed by controlled drying. A heat and mass transfer model is applied to predict the drying history of the single droplets. The approach is successfully evaluated through studying the inactivation of $\beta$-galactosidase during drying. The heat and mass transfer model supplemented with inactivation kinetics provided reasonable prediction of the residual enzyme activity after drying. In addition, the inactivation kinetics could be directly extracted from single droplet experiments rather than using the kinetics from separate heating experiments. Finally, it was demonstrated that the inactivation kinetics found with the single-drop experiments could satisfactorily predict the residual activity of $\beta$-galactosidase dried with a laboratory-scale spray dryer.
\end{abstract}

Keywords Enzyme - Temperature - Moisture content . Inactivation kinetics $\cdot$ Spray drying $\cdot$ Single droplet

J. Perdana $(\bowtie) \cdot$ M. A. I. Schutyser $\cdot$ R. M. Boom Food Process Engineering Group, Wageningen UR, P.O. Box 8129, 6700 EV Wageningen, The Netherlands e-mail: jimmy.perdana@wur.nl

M. B. Fox

NIZO Food Research,

P.O. Box 20, 6710 BA Ede, The Netherlands

e-mail: martijn.fox@nizo.nl

\section{Introduction}

Spray drying belongs to the most common drying techniques for liquid food products. The fine atomisation of the product and the subsequent fast evaporation of water make it especially suitable to formulate heat-sensitive products (Xin Huang et al. 2006; Fang and Bhandari 2010). Despite the relative mild conditions during drying, (partial) inactivation of bioactive compounds such as enzymes, antioxidants and vitamins cannot be avoided. Optimisation of the spray drying conditions and addition of stabilizers is often required to retain maximum activity (Ré 1998; Peighambardoust et al. 2011; Sansone et al. 2011). In practice, numerous expensive pilot-scale trials are executed to explore different product formulations and to find optimum drying conditions.

Modelling tools are frequently used to accelerate process development and optimisation in spray drying. The availability of reliable inactivation kinetics - usually highly product specific - is a prerequisite for this. Kinetic models require experimental data from drying experiments for parameter calibration. Pilot-scale experiments are not ideal for this as they are expensive, time-consuming, and involve the evaluation of complex process conditions. A more efficient alternative is the application of small-scale representative drying experiments.

Once reliable inactivation kinetics are obtained, a process model of the dryer can be used to predict the impact of the drying on the remaining ingredient activity. Subsequently, the model can be used to approximate optimal drying conditions and product formulations in a more systematic way (Wijlhuizen et al. 1979; Luyben et al. 1982; Meerdink and van't Riet 1991; Millqvist-Fureby et al. 1999; Coumans 2000).

Small-scale spray drying has been carried out in laboratory-scale spray dryers (Gianfrancesco et al. 2010; Li et al. 2010; Wu et al. 2011). However, major differences 
between laboratory and industrial spray dryers are the smaller droplet size, caused by the different method of atomisation, and the shorter residence time in the laboratory spray dryer (Goula and Adamopoulos 2004; Filková et al. 2006). Since the laboratory spray dryer can (due to its design and dimensions) only cover a limited range of droplet sizes and drying times and it produces droplets with a size distribution (not monodisperse), it is virtually impossible to extract sufficient representative experimental data to calibrate a kinetic model.

Another approach is the drying of single droplets under well-controlled conditions. In this approach a small droplet is generated, immobilised, and subsequently dried by contacting it with well-defined drying air. Examples are drying of a droplet that is non-intrusively levitated using for example acoustic, aerodynamic or electromagnetic levitation (Adhikari et al. 2000; Sloth et al. 2006; Schiffter and Lee 2007), intrusively levitated that is in pendant or filament (Chuchottaworn et al. 1984; Ali Al Zaitone and Tropea 2011), or that is deposited on a flat surface (Perdana et al. 2011a).

In this study, the latter method is followed (Perdana et al. 2011a). The major advantages of this method are the possibility to vary droplet size and residence time, and to dry multiple droplets at once to obtain higher volume of sample. The minimum droplet diameter can be adjusted to $150 \mu \mathrm{m}$ which is only slightly bigger than the typical droplet size in industrial spray dryers; a comparable droplet size is critical to accurately mimic the kinetics in spray drying (Adhikari et al. 2000; Vehring et al. 2007). The challenge in using this approach is the presence of the flat surface. This surface for example affects the spherical shape of the droplet. Therefore, a hydrophobic surface is used to minimize the contact between the droplet and the surface and to retain the spherical shape. Other differences introduced by the presence of the surface are the air flow velocity and the air temperature near the droplet, which deviate from the bulk conditions (Schlichting and Gersten 2000). By monitoring the air temperature near the droplet and by modelling the air flow and heat transfer across the drying surface, the influence of the surface on the drying conditions can be quantified.

This study focuses on the drying of the enzyme $\beta$ galactosidase suspended in a maltodextrin matrix. The enzyme $\beta$-galactosidase is selected as the model enzyme in this study, because it is an industrial relevant enzyme applied for production of lactose-hydrolysed milk and whey. Additionally, its activity can be easily determined and its inactivation kinetics has been studied before, though under steady-state conditions, providing strong basis for this study (Yamamoto and Sano 1992; Yoshioka et al. 1994; Perdana et al. 2011b). The inactivation kinetics of $\beta$-galactosidase from the previous studies were combined with the heat and mass transfer model to predict the residual activity of $\beta$ - galactosidase during the single droplet drying experiments. Finally, the predictive value of the model was also checked by drying of $\beta$-galactosidase in a laboratory spray dryer system.

\section{Modelling and Statistical Evaluation}

This section consists of four parts: (1) model description for a single droplet drying, (2) modelling temperature and air flow distribution across the flat plate, (3) inactivation kinetics of $\beta$ galactosidase, and (4) parameter optimisation and statistical evaluation.

\section{Model Description for Single Droplet Drying}

In analogy to several previous studies, a heat and mass transfer model is used to describe the drying of a sessile single droplet (Sloth et al. 2006; Straatsma et al. 2007; Mezhericher et al. 2008). The sessile droplet is approximated as a spherical droplet, and it is thus assumed that the diffusion occurs only in the radial direction. For the small droplet sizes considered, the temperature gradient inside the droplet could be neglected. This assumption is valid if the Biot number $(\mathrm{Bi})<0.1$. $\mathrm{Bi}$ is defined as the ratio of external heat transfer (between air and droplet) and the internal heat transfer (in the droplet, Incropera and De Witt 1985).

$B i=\frac{h d_{\mathrm{d}}}{\lambda_{\mathrm{d}}}$

In this study, $B i$ is around 0.02 .

The following differential equation is used to describe the droplet mass change in time

$$
-\frac{d m_{\mathrm{d}}}{d t}=k_{\mathrm{c}} 4 \pi R_{\mathrm{d}}^{2} \frac{M_{\mathrm{w}}}{R}\left(\frac{a_{\mathrm{w}} P_{\mathrm{w}}^{\mathrm{sat}}}{T_{\mathrm{d}}}-\frac{P_{\infty}}{P_{\infty}}\right)
$$

where $m_{\mathrm{d}}$ is the mass of the droplet, $t$ is the time, $k_{\mathrm{c}}$ is the mass transfer coefficient, $R_{\mathrm{d}}$ is the droplet radius, $M_{\mathrm{w}}$ is the molecular weight of water, $R$ is the ideal gas constant, $a_{\mathrm{w}}$ is the water activity, $P_{\mathrm{w}}$ sat is the saturated vapour of water at $T_{\mathrm{d}}, T_{\mathrm{d}}$ is the temperature of the droplet, $P_{\infty}$ is the vapour partial pressure in the bulk air and $T_{\infty}$ is the bulk air temperature.

The developing moisture gradient inside the droplet is described by Fickian diffusion

$$
\frac{\partial C_{\mathrm{w}}}{\partial t}=D_{\mathrm{w}, \mathrm{d}} \frac{\partial}{\partial r}\left(\frac{\partial C_{\mathrm{w}}}{\partial r}\right)
$$

Where $C_{\mathrm{w}}$ is the water concentration, $D_{\mathrm{w}, \mathrm{d}}$ is the effective diffusion coefficient of water in the droplet and $r$ is 
the radial coordinate. The boundary conditions applied here are

$t=0,0 \leq r \leq R_{\mathrm{d}} ; \quad \frac{d C_{\mathrm{w}}}{d r}=0$

$t=t, r=0 ; \quad \frac{d C_{\mathrm{w}}}{d r}=0$

$t=t, r=R_{\mathrm{d}} ; \quad-D_{\mathrm{w}, \mathrm{d}} \frac{d C_{\mathrm{w}}}{d r}=k_{\mathrm{c}} 4 \pi R_{\mathrm{d}}^{2} \frac{M_{\mathrm{w}}}{R}\left(\frac{a_{\mathrm{w}} P_{\mathrm{w}}^{\text {sat }}}{T_{\mathrm{d}}}-\frac{P_{\infty}}{T_{\infty}}\right)$

The temperature change of the droplet is described by the following enthalpy balance:

$\left(m_{\mathrm{w}} c_{\mathrm{p}, \mathrm{w}}+m_{\mathrm{s}} c_{\mathrm{p}, \mathrm{s}}\right) \frac{d T_{\mathrm{d}}}{d t}=h_{\mathrm{d}} 4 \pi R_{\mathrm{d}}^{2}\left(T_{\infty}-T_{\mathrm{d}}\right)-\frac{d m_{\mathrm{d}}}{d t} H_{\mathrm{lv}}$

where $m_{\mathrm{s}}$ is the mass of the solute, $c_{\mathrm{p}, \mathrm{w}}$ and $c_{\mathrm{p}, \mathrm{s}}$ the heat capacity of the water and the solute respectively, $h_{\mathrm{d}}$ the heat transfer coefficient to the droplet through convection and $H_{\mathrm{lv}}$ is the evaporation enthalpy of water.

The coupled heat and mass transfer models were solved numerically using 100 radial layers in the droplet. In each layer the same solute mass $\left(m_{\mathrm{s}}\right)$ was calculated according to

$m_{\mathrm{s}}=C_{\mathrm{s}, 0} \frac{V_{\mathrm{d}, 0}}{n}$

where $C_{\mathrm{s}, 0}$ is the initial solute concentration and $V_{\mathrm{d}, 0}$ is the initial volume of the droplet.

Since the initial solute concentration is assumed homogenous, the initial solute mass distribution is approximated with the initial volume distribution. The radial position of the $i^{\text {th }}$ layer from the centre of the droplet can be calculated as follows

$r_{i}=\left(i \cdot \frac{R_{\mathrm{d}}{ }^{3}}{n}\right)^{1 / 3}$

where $n$ is the total number of layers for numerical integration. The layer thickness $\Delta r$ is

$\Delta r_{i}=\left\{\begin{aligned} r_{i}, & i=1 \\ r_{i}-r_{i-1}, & i \geq 2\end{aligned}\right.$

The volume of each layer $V$ is then

$V=\frac{m_{\mathrm{w}}}{\rho_{\mathrm{w}}}+\frac{m_{\mathrm{s}}}{\rho_{\mathrm{s}}}$

where $\rho_{\mathrm{w}}$ and $\rho_{\mathrm{s}}$ are the densities of water and solute, respectively. The average water concentration is then defined as

$C_{\mathrm{w}}=\frac{m_{\mathrm{w}}}{V}=\frac{m_{\mathrm{w}}}{\frac{m_{\mathrm{w}}}{\rho_{\mathrm{w}}}+\frac{m_{\mathrm{s}}}{\rho_{\mathrm{s}}}}$
Reorganizing Eq. 9. results in

$m_{\mathrm{w}}=\frac{m_{\mathrm{s}}}{\rho_{\mathrm{s}}} \frac{C_{\mathrm{w}}}{\left(1-\frac{C_{\mathrm{w}}}{\rho_{\mathrm{w}}}\right)}$

The droplet shrinks upon drying due to the evaporation of water. This shrinkage influences the heat and mass transfer within the droplet. The model was therefore corrected to describe the decrease of layer thickness due to shrinkage (Farid 2003). This correction was based on the water concentration in every layer at $t>0$ that is calculated from Eq. 3 (Crank 1990). From the water concentration, the new volume of the layer was recalculated as

$V=\frac{m_{\mathrm{s}}}{\rho_{\mathrm{s}}}\left(1+\frac{1}{\left(\rho_{\mathrm{w}}-C_{\mathrm{w}}\right)}\right)$

The radial coordinate of every partition was corrected using this new volume. The radius of the $i$ th partition is

$r_{i}=\left(\frac{3\left(\sum_{0}^{i} V_{i}\right)}{4 \pi}\right)^{1 / 3}$

The thickness of every partition could be recalculated using Eq. 7. To solve the model, several closure equations like heat and mass transfer coefficient, water activity, moisture diffusion coefficient, and vapour pressure are required, which are tabulated in Table 1.

Modelling Temperature and Air Flow Distribution Across the Flat Plate

In this study, the droplet was deposited on a flat plate. The drawback of this configuration is that in addition to heat transfer from the air to the droplet, also heat is transferred from the air to the flat plate through convection. This heat is further transferred from the plate to the droplet through conduction. It is of major importance to quantify the heat transfer between the flat plate and the droplet and compare this to the convective heat transfer via the drying air. The conductive heat transfer between the flat plate and the droplet is preferably as low as possible, when one wants to mimic the drying of a droplet suspended in air. By using a hydrophobic surface, the contact area for conductive heat transfer has already been reduced. Furthermore, the temperature in the air near the flat plate deviates from the bulk air temperature affecting the drying process. Therefore a model description of the temperature gradients within the plate and in the air near the plate was developed.

To minimize turbulence (eddy formation) near the edge of the depositing plate, a thin flat plate is used rather than a blunt-edged plate. However, the presence of the flat plate still influences the flow pattern of the drying air above the plate, i.e. near the droplet (Fig. 1). A boundary layer model 
Table 1 The closure equations used in drying model

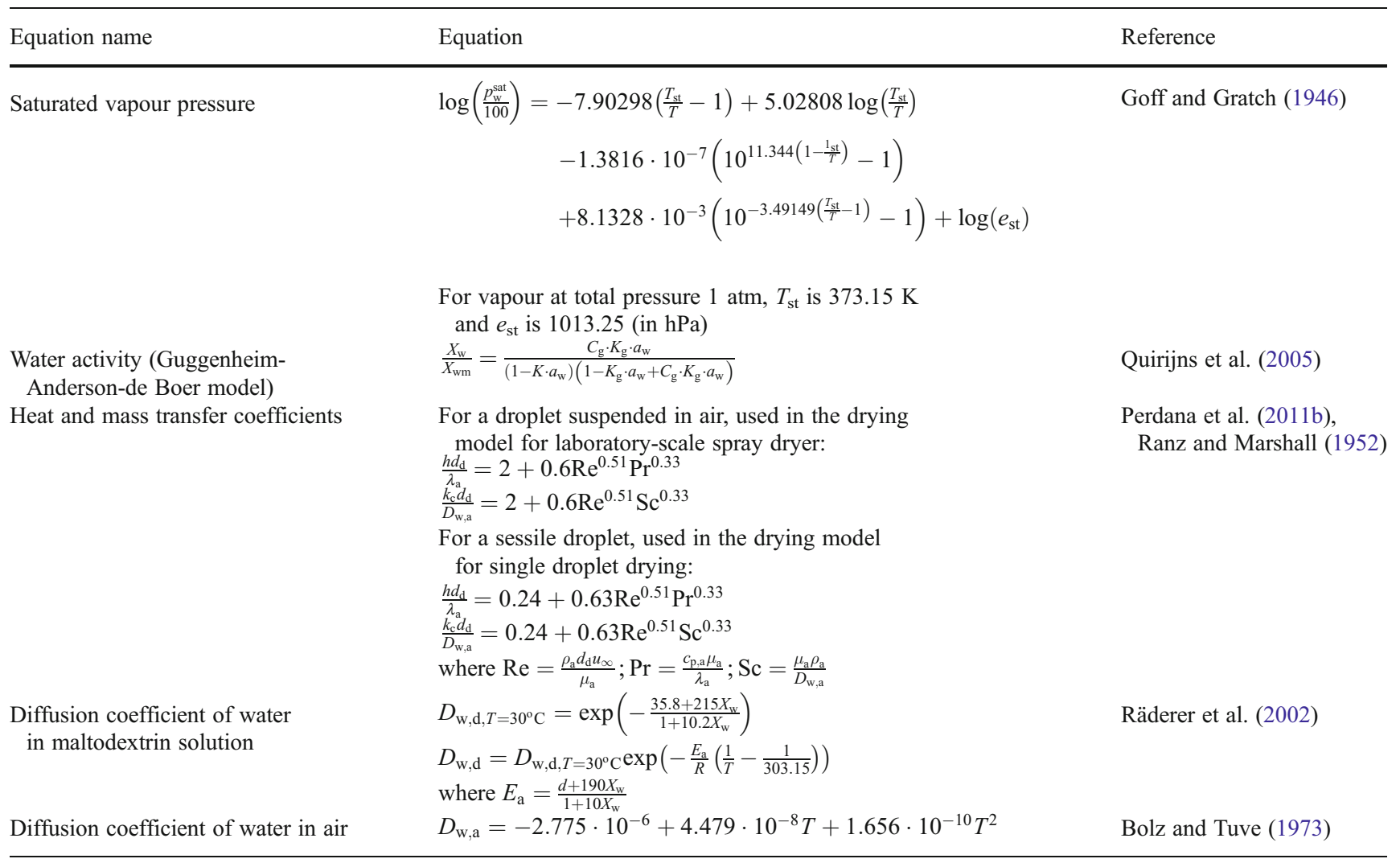

according to Mosaad (1999) is used to describe the air flow and temperature distribution across the flat plate: a hydrodynamic boundary layer is defined for the air flow distribution and a thermal boundary layer for the temperature distribution

$\frac{u}{u_{\infty}}=\frac{3}{2}\left(\frac{z}{\delta}\right)-\frac{1}{2}\left(\frac{z}{\delta}\right)^{3} ; \quad 0 \leq z \leq \delta$

$\frac{T-T_{\infty}}{T_{\mathrm{p}, x}-T_{\infty}}=1-\frac{3}{2}\left(\frac{z}{\delta_{\mathrm{t}}}\right)+\frac{1}{2}\left(\frac{z}{\delta_{\mathrm{t}}}\right)^{3} ; \quad 0 \leq z \leq \delta_{\mathrm{t}}$

where $z$ is the height coordinate from the surface of the flat plate, $u$ is the air velocity at $z, u_{\infty}$ is the bulk velocity of air, $v$

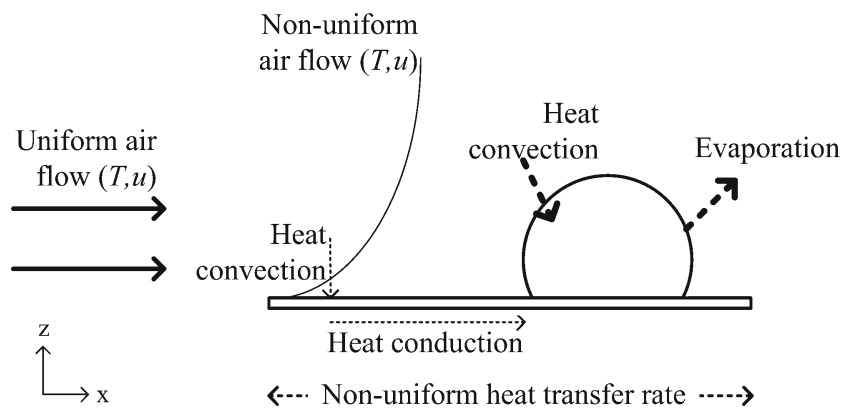

Fig. 1 Sketch of a single droplet drying on a flat plate with the air flow pattern and governing heat transfer processes indicated. The sessile droplet is dried on a thin plate consisting of a hydrophobic membrane $(0.15 \mathrm{~mm})$ on top of a stainless steel platform $(1.00 \mathrm{~mm})$ is the kinematics viscosity of air, $T_{\mathrm{p}, x}$ is the temperature of the surface of the flat plate at distance $x$ (at the front edge of the flat plate, $x=0), T_{\infty}$ is the bulk air temperature, $\delta$ is the hydrodynamic boundary layer at distance $x$ and $\delta_{\mathrm{t}}$ is the thermal boundary layer. The hydrodynamic boundary layer for $u=0.99 u_{\infty}$ is (Schlichting and Gersten 2000)

$\delta=5 \sqrt{\frac{v x}{u_{\infty}}}$

and $\delta_{\mathrm{t}}$ is thermal boundary layer at distance $x$

$\delta_{t}=\left\{\begin{array}{cc}\operatorname{Pr}^{-1 / 3}, & \operatorname{Pr} \leq 1 \\ \operatorname{Pr}, & \operatorname{Pr}>1\end{array}\right.$

The heat transfer coefficient between the air and the flat plate $h_{\mathrm{p}}$ is approximated by (Thirumaleshwar 2009)

$h_{\mathrm{p}}=0.332 \frac{\lambda_{\mathrm{a}}}{x^{1 / 2}}\left(\frac{u_{\infty}}{v}\right) \operatorname{Pr}^{1 / 3} ; \quad \operatorname{Pr}=\frac{c_{\mathrm{p}, \mathrm{a}} \mu_{\mathrm{a}}}{\lambda_{\mathrm{a}}}$

where $\lambda_{\mathrm{a}}$ is the thermal conductivity of air, $\operatorname{Pr}$ is the Prandtl number of air, $c_{\mathrm{p}, \mathrm{a}}$ is the heat capacity of air and $\mu_{\mathrm{a}}$ is the dynamic viscosity of air. The value of $\lambda_{\mathrm{a}}, c_{\mathrm{p}, \mathrm{a}}$ and $\mu_{\mathrm{a}}$ are temperature dependent; in Eq. 17, the value are evaluated at $T=\left(T_{\mathrm{p}}+T_{\infty}\right) / 2$.

The heat transfer coefficient decreases as a function of the $x$ coordinate (Eq. 17) and is calculated locally. It was 
estimated numerically; i.e. assuming a $\Delta x$ at distance $L$ from the front side of the plate, the average heat transfer coefficient is obtained by integrating $h_{\mathrm{p}}$ along $\Delta x$

$h_{\mathrm{p}, \mathrm{avg}}=0.664 \frac{\lambda_{\mathrm{a}}}{v^{1 / 2}} \operatorname{Pr}^{1 / 3}\left(\left(\frac{u_{\infty}}{L}\right)^{1 / 2}-\left(\frac{u_{\infty}}{L+\Delta x}\right)^{1 / 2}\right)$

where $h_{\mathrm{p}, \text { avg }}$ is the average local heat transfer coefficient.

The non-uniform heat transfer rate across the plate contributes to the development of a temperature gradient within the plate. The temperature distribution within the plate is described with a one-dimensional partial differential equation (Kakac and Yener 1993). It is assumed that no temperature gradient in the $y$ direction (perpendicular to the air flow direction) and in the $z$ direction (within the plate; because of the small thickness, i.e. $150 \mu \mathrm{m})$

$\frac{\partial T_{\mathrm{p}}}{\partial t}=\frac{\lambda_{\mathrm{p}}}{\rho_{\mathrm{p}} c_{\mathrm{p}, \mathrm{p}}}\left(\frac{\partial^{2} T_{\mathrm{p}}}{\partial x^{2}}+\frac{h_{\mathrm{p}, \mathrm{avg}}\left(T_{\infty}-T_{\mathrm{p}}\right)}{Z \lambda_{\mathrm{p}}}\right)$

where $\rho_{\mathrm{p}}$ is the density of the plate, $Z$ is the thickness of the flat plate and $\lambda_{\mathrm{p}}$ is the thermal conductivity of the flat plate. The boundary layer applied here are that near the droplet the flat plate temperature is equal to the droplet temperature and at the edge of the flat plate (far from the droplet) the temperature gradient of the flat plate is 0 .

Equations 14 and 19 were solved numerically to estimate the temperature distribution history within and above the flat plate. The predictions were validated by simple temperature measurements at different heights above the plate.

To estimate the conductive heat transfer between the surface and the droplet and compare it to the convective heat transfer between the air and the droplet, the conductive heat flux $Q$ through the contact surface of the droplet was estimated according to

$Q=\lambda_{\mathrm{p}} 2 \pi R_{\mathrm{d}} z \frac{\Delta T_{\text {cond }}}{\Delta x_{\text {cond }}}$

where $\Delta T_{\text {cond }} / \Delta x_{\text {cond }}$ is the temperature gradient in the partition layer of the flat plate that is closest the droplet. It was found that the conductive heat flux was smaller than 5\% of the total heat transferred to the droplet regardless of its position. Therefore, it can be safely assumed that most heat is transferred via convective heat transfer.

Inactivation Kinetics of $\beta$-galactosidase

The inactivation rate of the $\beta$-galactosidase is affected by the temperature and moisture content of the droplet, which both change with time. A kinetic inactivation model for $\beta$ galactosidase is developed in earlier work and calibrated using constant heating experiments (Perdana et al. 2011b). In the latter experiments, the suspended enzyme is exposed to various temperature-moisture value combinations for a specific time and the remaining enzyme activity is measured. The inactivation kinetics are described by a twostep inactivation process and the observed inactivation coefficient $\left(k_{\mathrm{obs}}\right)$ is described as

$k_{o b s}=\left(\frac{K_{1}}{1+K_{1}}\right) k_{2}$

where

$$
\begin{aligned}
K_{1}= & \exp \left(\frac{\Delta \Delta S^{\ddagger}{ }_{1, \mathrm{w}}}{R}-\frac{\Delta \Delta H^{\ddagger}}{R T_{\text {ref }}}\right) \\
& \exp \left(-\frac{\Delta \Delta H^{\ddagger}{ }_{1, \mathrm{w}}}{R}\left(\frac{1}{T}-\frac{1}{T_{\text {ref }}}\right)\right) \exp \left(-\frac{f\left(1-x_{\mathrm{w}}\right)}{R T}\right)
\end{aligned}
$$

$$
\begin{aligned}
k_{2}=\frac{k_{\mathrm{B}} T}{\mathrm{~h}} & \exp \left(\frac{\Delta S^{\ddagger}{ }_{2, \mathrm{w}}}{R}-\frac{\Delta H_{2, \mathrm{w}}^{\ddagger}}{R T_{\text {ref }}}\right) \exp \left(\frac{\Delta H^{\ddagger}{ }_{2, \mathrm{w}}}{R T}\left(\frac{1}{T}-\frac{1}{T_{\text {ref }}}\right)\right) \\
& \exp \left(-\frac{\Delta H^{\ddagger}{ }_{2, \mathrm{w}}-\Delta H_{2, \mathrm{w}}^{\ddagger}}{R}\left(\frac{1}{T}-\frac{1}{T_{\text {int }}}\right) \exp \left(-g \frac{x_{\mathrm{w}}}{1-c_{\mathrm{w}}}\right)\right)
\end{aligned}
$$

where $K_{1}$ is the reversible unfolding equilibrium constant, $k_{2}$ is the complete denaturation rate constant, $\Delta \Delta S_{1, \mathrm{w}}{ }^{*}$ is the activation entropy difference between the unfolding and refolding reactions in pure water, $\Delta \Delta H_{1, \mathrm{w}}{ }^{\ddagger}$ is the activation enthalpy difference between the unfolding and refolding reactions in pure water, $k_{\mathrm{B}}$ is Boltzmann's constant, $h$ is the Planck's constant, $\Delta S_{2, \mathrm{w}}{ }^{\star}$ is the activation entropy of complete denaturation in pure water, $\Delta H_{2, \mathrm{w}}{ }^{\ddagger}$ is the activation enthalpy in pure water, $\Delta H_{2, \mathrm{~m}}{ }^{\dagger}$ is the activation enthalpy in pure solid form (i.e. no moisture), $f$ describes the effect of moisture content on conformational stability of the enzyme, $g$ describes the effect of moisture content on the irreversible inactivation (second step) kinetic constant of the enzyme and $T_{\text {in }}$ is the intercept temperature at which $k_{2, \mathrm{w}} / k_{2, \mathrm{~s}}=1$.

Alternatively, the enzyme inactivation can also be regarded as a one-step inactivation process in which the native enzyme is irreversibly inactivated. Then

$k_{o b s}=k_{2}$

An advantage is that this approach involves only five parameters to fit instead of eight in the two-step model. 
The effect of the temperature is then still described using the transitional state theory as shown in Eq. 23.

\section{Parameter Optimization and Statistical Evaluation}

To directly extract the kinetics from single droplet drying experiments the following approach was taken:

1. The temperature and moisture content histories of several droplets were predicted using the drying model (Eqs. 3 and 4).

2. The inactivation kinetic constants were optimised to fit the measured residual enzyme activities after the drying for all droplets simultaneously.

The parameter optimisation was carried out using a nonlinear least square method solved using the LevenbergMarquardt algorithm (Seber and Wild 2005). The confidence interval of the parameters $(p=0.95)$ were estimated using the Hessian matrix, which was again derived from the Jacobian matrix of the solution (Richard et al. 2005). All calculations were performed with MATLAB version 7.10.

\section{Materials and Methods}

\section{Sample Preparation}

The enzyme, $\beta$-galactosidase from Aspergillus oryzae (SigmaAldrich, Germany) was dissolved in a buffer solution. The solution was then filtered with a $0.2-\mu \mathrm{m}$ Minisart sterile sieve (Sartorius Stedim Biotech SA, Germany) and stored overnight in a refrigerator. The maltodextrin, with DE 4-7 (SigmaAldrich, Germany), was dissolved in a buffer. The buffer was prepared from 0.2 $\mathrm{M} \mathrm{Na}_{2} \mathrm{HPO}_{4}$ (Sigma-Aldrich, Germany) and $0.1 \mathrm{M}$ citric acid $\left(\mathrm{C}_{6} \mathrm{H}_{8} \mathrm{O}_{7}\right)$ solutions (Sigma-Aldrich, Germany). The $\mathrm{pH}$ of the buffer was adjusted to $6.00 \pm 0.01$.

The feed for single droplet drying experiments was prepared by mixing $600 \mu \mathrm{L} 2.5 \% \mathrm{w} / \mathrm{w}$ enzyme solution and $2,400 \mu \mathrm{L} 25 \%$ maltodextrin solution. The feed for the laboratory-scale spray dryer was prepared by mixing $4 \mathrm{~mL}$ $2 \% w / w$ enzyme solution and $96 \mathrm{~mL} 20.8 \% \mathrm{w} / \mathrm{w}$ maltodextrin solution. A lower enzyme concentration is used during the laboratory-scale spray dryer experiments. The major reason was that a larger sample volume could be easily obtained for performing the enzyme activity test. This is allowed, since at low enzyme concentration, the inactivation kinetics of $\beta$-galactosidase is not affected by its concentration (Yamamoto and Sano 1992).

\section{Deposited Droplet Drying Experiments}

The single droplet drying experiments involved the subsequent steps: droplet generation, droplet drying, rehydration and enzyme activity measurement. A micro-dispenser was used to generate the droplet as described by Perdana et al. (2011a). The droplet was deposited on a polypropylene membrane (Akzo Nobel Faser Ag., The Netherlands) positioned on a platform from stainless steel slab; the thickness of the membrane was $0.15 \mathrm{~mm}$, and the stainless steel slab was $1 \mathrm{~mm}$. The droplet was then positioned in a drying tunnel (Fig. 2). By guiding the drying air through a porous medium, a uniform flow distribution could be achieved within the tunnel. The tunnel was insulated and heated with heating oil to ensure that the air temperature was constant. The temperature and relative humidity of the air bulk air was monitored using SHT75 temperature and humidity sensor (Sensiron AG, Switzerland). The temperature near the droplet was monitored using a thermocouple Type $\mathrm{K}$ ( $\mathrm{NiCr}-\mathrm{NiAl}$; $\mathrm{RS}$ Component, United Kingdom) with probe diameter of $250 \mu \mathrm{m}$. Furthermore, the setup was equipped with a $\mu$ Eye $1480 \mathrm{ME}$ CCD camera with a lens with $\times 9$ magnification ratio (Imaging Development Systems GMBH, Germany) to monitor the droplet geometry evolution during drying.

The single droplet drying experiments were performed using dry air $(\mathrm{RH}=0.0 \%)$, preheated to a temperature between 80 and $110{ }^{\circ} \mathrm{C}$ and a bulk air velocity of $0.20 \mathrm{~m} / \mathrm{s}$. After drying, the resulting powder particle was dissolved in $50 \mu \mathrm{L}$ buffer solution, stored overnight in the refrigerator, and then the enzyme activity was measured.

\section{Laboratory-Scale Spray Drying Experiments}

The enzyme solution was dried with a Buchi B-190 spray dryer (Buchi Labortechnik AG, Switzerland). The residence
Fig. 2 Schematic drawing of the drying tunnel, side view $(S)$ and top view $(T)$

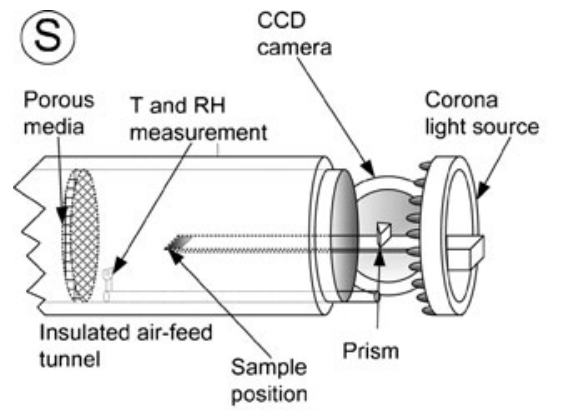


time of the particle inside this small spray dryer can be as short as $1 \mathrm{~s}$. Based on the equipment specification, the particle diameter after drying was between 2 and $25 \mu \mathrm{m}$. The inlet air temperature was $180{ }^{\circ} \mathrm{C}$, and the outlet air temperature varied between 80 and $130{ }^{\circ} \mathrm{C}$. Subsequently, around $1 \mathrm{~g}$ of powder was taken and dried further in a heating chamber at $105{ }^{\circ} \mathrm{C}$ for $72 \mathrm{~h}$ to determine the moisture content of the powder after spray drying. Additionally, a $0.200-\mathrm{g}$ powder sample was reconstituted to $3.80 \mathrm{~mL}$ buffer solution and analysed for its residual enzyme activity.

Measurement of the Residual Activity of $\beta$-galactosidase

The residual activity of $\beta$-galactosidase was measured using an $o$-nitrophenyl- $\beta$-D-galactopyranoside (ONPG) assay (SigmaAldrich, Germany) according to Perdana et al. (2011b). The absorbance of the samples incubated in ONPG solution was immediately measured after incubation at a wavelength $420 \mathrm{~nm}$ using a spectrophotometer (Beckman Coulter, Inc., USA).

\section{Particle Size Measurement}

Approximately $1 \mathrm{~g}$ of the spray-dried sample was dried further in a heating chamber at $105{ }^{\circ} \mathrm{C}$ for $72 \mathrm{~h}$ to reduce the moisture content and to avoid particle agglomeration. Afterwards, the particle size distribution of the sample was measured using Mastersizer Scirocco 2000 (Malvern Instrument LTD, England).

\section{Results and Discussion}

\section{Droplet Geometry Evolution}

Snapshots of a deposited droplet during the drying process are shown in Fig. 3. The droplet shrinks uniformly before $30 \mathrm{~s}$, and then starts to develop wrinkles. The uneven shrinkage after $60 \mathrm{~s}$ suggests that a thin non-flowing layer is developed, which cannot accommodate a homogenous shrinkage (Walton and Mumford 1999). Instead, it collapses which leads to an irregular shape of the particle.

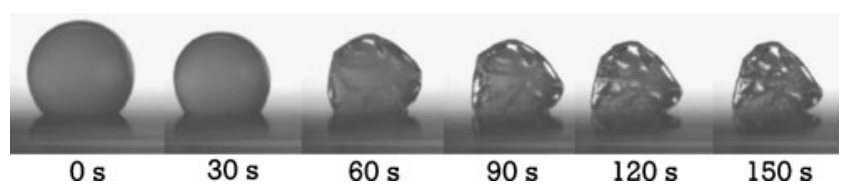

Fig. 3 Droplet geometry change during a single droplet drying experiment at an air temperature of $80^{\circ} \mathrm{C}$, an absolute air humidity of $0 \mathrm{~g} / \mathrm{kg}$ dry air, a bulk air velocity of $0.20 \mathrm{~m} / \mathrm{s}$, an initial droplet height of $800 \mu \mathrm{m}$ and an initial droplet moisture content of $80 \% \mathrm{w} / \mathrm{w}$

\section{Drying Model}

In the heat and mass transfer model, the sessile droplet is assumed to be a perfect sphere. This assumption reduces the complexity of the model and is acceptable since the initial sessile droplet has a very high contact angle $\left(>130^{\circ} \mathrm{C}\right)$ and also the final powder particle remains approximately spherical, as shown in Fig. 3. The predicted temperature and moisture profiles are shown in Fig. 4.

The model predicts that the moisture content at the surface decreases faster than in the centre of the droplet and reaches a moisture content close to $0 \%$ at around $35 \mathrm{~s}$. This is in line with the visual observations, i.e. the occurrence of wrinkles indicating the presence of a thin dry layer. As shown in Fig. 4 (bottom), at $t=31 \mathrm{~s}$, the moisture content gradient near the surface of the droplet is very steep, indicating that a very thin layer near the droplet surface is very dry. The model also predicts that the droplet radius does not change any more after approximately $60 \mathrm{~s}$ of drying. This is also in line with the visual observations.

The droplet temperature at the beginning ( $t<40 \mathrm{~s}$ ) of the drying process is equal to the corresponding wet bulb temperature of the heating air (Fig. 4, top). When the moisture content near the surface of the droplet decreases to less than $100 \mathrm{~kg} / \mathrm{m}^{3}$, the droplet temperature starts to increase. At this point the water evaporation rate decreases together with the lower vapour pressure at the droplet surface $\left(a_{\mathrm{w}}<1\right)$. While the evaporation rate decreases, the heat transfer into the droplet continues and causes an accumulation of heat, observed as an increase in droplet temperature.

\section{Predicting the Residual Enzyme Activity After Drying}

The single droplet drying method is applied to dry $\beta$ galactosidase suspended in a maltodextrin matrix. The inactivation kinetics of $\beta$-galactosidase determined with independent experimental data was combined with the heat and mass transfer model to predict the residual enzyme activity after drying (Perdana et al. 2011b). Subsequently, the predicted enzyme activity is compared to the drying results. In modelling the inactivation of $\beta$-galactosidase, the $\mathrm{pH}$ change due to decreasing moisture content was neglected. This is allowed since most of the enzyme activity loss takes place at high moisture content where the presence of the added buffer stabilizes the $\mathrm{pH}$. Furthermore, at lower moisture content, the enzyme activity loss is negligible at the time scale of drying applied. The model predictions and the experimental data are shown in Fig. 5. As shown in Fig. 5, the heat and mass transfer model using the independent kinetic inactivation model for $\beta$ galactosidase is in reasonable agreement with the experimental data.

Both the predictions and the experimental data show that the enzyme activity does not decrease during the initial 

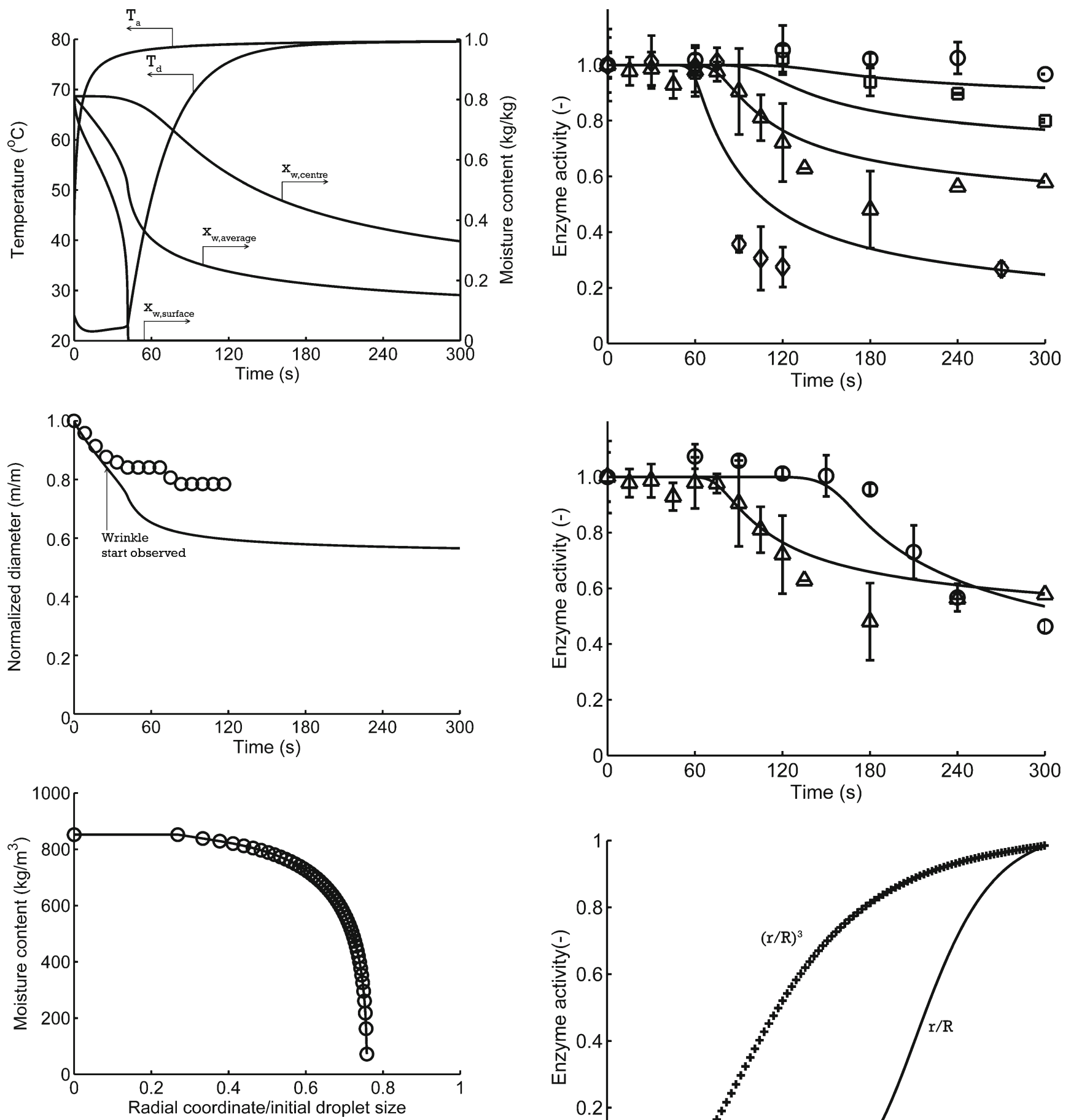

Fig. 4 Top temperature and moisture content history of a droplet dried during a single droplet drying experiment, $T_{\mathrm{a}}$ is the air temperature contacting the droplet, averaged as the air temperature at half droplet height; $T_{\mathrm{d}}$ is the droplet temperature; and $x_{\mathrm{w}}$ is the moisture content. Middle droplet radius change during drying from the visual monitoring (symbol) and the model (line). Bottom moisture content distribution inside the droplet at $t=32 \mathrm{~s}$, the symbols show the border of the partition for each layer. The drying is carried out at an air temperature of $80{ }^{\circ} \mathrm{C}$, a bulk air velocity of $0.20 \mathrm{~m} / \mathrm{s}$ and an absolute air humidity of $0 \mathrm{~kg} / \mathrm{kg}$ dry air. The initial moisture content is $80 \% \mathrm{w} / \mathrm{w}$ and the initial droplet height is $800 \mu \mathrm{m}$

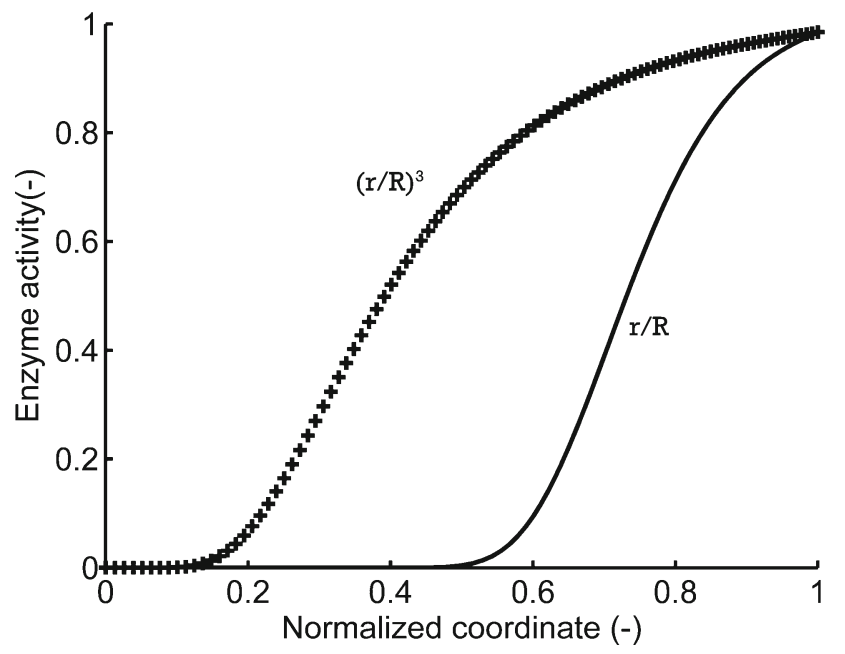

drying period $(<40 \mathrm{~s})$ because the temperature of the droplet, which is near the (low) wet bulb temperature. Then, a rapid inactivation rate is observed, which slowly declines to result in a final enzyme activity. The subsequent rapid inactivation can be explained by an increase in particle temperature. At 
4 Fig. 5 Top the residual enzyme activity after drying of a single sessile droplet at air temperatures of $80{ }^{\circ} \mathrm{C}$ (empty circles), $87{ }^{\circ} \mathrm{C}$ (empty squares), $95{ }^{\circ} \mathrm{C}$ (empty triangles) and $110^{\circ} \mathrm{C}$ (empty diamonds) for an initial droplet diameter of $800 \mu \mathrm{m}$. Middle the effect of initial droplet size on residual enzyme activity for an initial droplet diameter of $800 \mu \mathrm{m}$ (empty triangles) and 1,400 $\mu \mathrm{m}$ (empty circles). The error bar shows the standard deviation of the data. The predictions (solid line) are based on the inactivation kinetics of $\beta$-galactosidase from the constant heating experiments. Bottom the residual activity of $\beta$ galactosidase as a function of the radial coordinate (solid line) and of the volumetric coordinate (symbols) after drying of a droplet with an initial diameter of $800 \mu \mathrm{m}$ at an air temperature of $95^{\circ} \mathrm{C}$ for $300 \mathrm{~s}$

this point the heat transfer is not compensated by sufficient water evaporation. The increase in temperature has especially impact on the enzyme present in the centre of the droplet as the moisture content in the centre is still high as also reported for drying of other heat-sensitive products (Chen and Patel 2007; Langrish 2009). After a while the enzyme inactivation rate decreases and the residual enzyme activity in the particle is obtained. The enzyme inactivation rate decreases because of the decreasing moisture content, especially near the surface of the droplet and finally also in the centre of the droplet. Most of the residual active enzyme is located near the surface of the particle as shown in Fig. 5 (bottom). It can be concluded that the different moisture content history at different locations in the droplet determines the large differences in residual enzyme activity across the droplet radius. A strategy that might be followed to retain maximum enzyme activity is to minimize the presence of enzyme in the centre of the droplet. This can for example be achieved by drying the enzyme in a droplet that forms a hollow sphere upon drying (Etzel et al. 1996) or by applying a coating of a concentrated enzyme solution on pre-dried particles.

The results also show that the initial droplet diameter determines the residual enzyme activity to a large extent. Figure 5 indicates that the residual activity is higher for smaller droplets. Although inactivation starts earlier in a smaller droplet, the critical region is shorter (i.e. the combination of high temperature and high moisture content in the centre of the droplet) compared to that in the larger droplet. This implies that with respect to enzyme inactivation, a smaller droplet size is preferred for spray drying.

\section{Direct Extraction of Inactivation Kinetic Parameters from Drying Experiments}

The parameters describing the specific inactivation kinetics of $\beta$-galactosidase in maltodextrin may be extracted directly from the single droplet drying results. This is preferred as these experiments are much less labour intensive and can be scaled out to facilitate a high throughput approach. If the method is reliable, the parameters for $\beta$-galactosidase inactivation directly obtained from single droplet drying experiments should be similar to the ones obtained from the separate heating experiments (Perdana et al. 2011b).

Both the one-step and the two-step inactivation models were evaluated to describe the experimental drying data. The results of the parameter optimisation are compared to the parameters from the earlier study (Table 2).

It can be observed that the parameters obtained from the drying experiments differ from the parameter values from the heating experiments (Table 2). This can be explained by the fact that the inactivation during single droplet drying experiments occurs primarily during a very short critical period. This critical period is dictated by the drying history and involves temperatures and moisture content values that lead to rapid inactivation. Therefore, the parameter values are optimised such that they specifically describe the inactivation during this critical period. This explanation is further confirmed by implementing the one-step inactivation model, which is also able to describe the inactivation during drying experiments well. The data from the heating experiments were obtained at many different temperature and moisture content
Table 2 The parameter values for the inactivation kinetics of $\beta$-galactosidase estimated from heating experiments and from single droplet drying experiments

\footnotetext{
${ }^{\mathrm{a}}$ The uncertainty of the parameter is provided within $95 \%$ confidence interval

${ }^{\mathrm{b}}$ The values of the parameters are according to Perdana et al. (2011b)

${ }^{\mathrm{c}}$ Reference value, not fitted
}

\begin{tabular}{llll}
\hline Estimated parameter & Heating experiments & & \\
& & & Drying experiments \\
\cline { 3 - 4 } & & $\begin{array}{l}\text { Two-step inactivation model } \\
\text { (Eqs. 21, 22, and 23) }\end{array}$ & $\begin{array}{l}\text { One-step inactivation } \\
\text { model (Eq. 23) }\end{array}$ \\
\hline$\Delta \Delta S_{1}^{\ddagger}\left(\mathrm{J} \mathrm{mol}^{-1} \mathrm{~K}^{-1}\right)$ & $1.08 \cdot 10^{3} \pm 0.25 \cdot 10^{3}$ & $1.31 \cdot 10^{3} \pm 0.0063 \cdot 10^{3}$ & $\mathrm{NA}$ \\
$\Delta \Delta H_{1}^{\ddagger}\left(\mathrm{J} \mathrm{mol}^{-1}\right)$ & $3.57 \cdot 10^{5} \pm 0.81 \cdot 10^{5}$ & $4.86 \cdot 10^{5} \pm 0.023 \cdot 10^{5}$ & $\mathrm{NA}$ \\
$\Delta S_{2, \mathrm{w}}{ }^{\ddagger}\left(\mathrm{J} \mathrm{mol}^{-1} \mathrm{~K}^{-1}\right)$ & $6.75 \cdot 10^{2} \pm 1.17 \cdot 10^{2}$ & $5.49 \cdot 10^{2} \pm 0.097 \cdot 10^{2}$ & $1.88 \cdot 10^{3} \pm 0.00010 \cdot 10^{3}$ \\
$\Delta H_{2, \mathrm{w}}{ }^{\ddagger}\left(\mathrm{J} \mathrm{mol}^{-1}\right)$ & $3.28 \cdot 10^{5} \pm 0.40 \cdot 10^{5}$ & $2.76 \cdot 10^{5} \pm 0.063 \cdot 10^{5}$ & $7.74 \cdot 10^{5} \pm 0.00023 \cdot 10^{5}$ \\
$\Delta H_{2, \mathrm{~s}}{ }^{\ddagger}\left(\mathrm{J} \mathrm{mol}^{-1}\right)$ & $1.28 \cdot 10^{5} \pm 0.20 \cdot 10^{5}$ & $1.57 \cdot 10^{5} \pm 0.027 \cdot 10^{5}$ & $4.77 \cdot 10^{5} \pm 0.0010 \cdot 10^{5}$ \\
$m$ & $2.60 \cdot 10^{4} \pm 0.00094 \cdot 10^{4}$ & $8.92 \cdot 10^{3} \pm 0.0010 \cdot 10^{3}$ & $\mathrm{NA}$ \\
$p$ & $1.16 \pm 0.0056$ & $5.37 \pm 0.011$ & $5.67 \pm 0.00038$ \\
$T_{\text {int }}\left({ }^{\circ} \mathrm{C}\right)$ & $33.85 \pm 0.065$ & $-49.65 \pm 8.80$ & $8.25 \pm 0.026$ \\
$T_{\text {ref }}\left({ }^{\circ} \mathrm{C}\right)^{\mathrm{c}}$ & 68.50 & 68.50 & 68.50 \\
\hline
\end{tabular}


combinations and could be varied independently. Therefore, the values are based on a much wider data set, but having less data in the specific range that are relevant for spray drying.

Another reason for the difference between the kinetic parameters is that the parameter optimisation procedure forces the model to describe the residual enzyme activity after the drying. By doing so, any uncertainties in the heat and mass transfer model are neglected. However, from earlier observations, it was concluded that the heat and mass transfer model could predict the droplet shrinkage and the residual enzyme activity using the kinetic parameters from the heating experiments reasonably accurate. Therefore, it is believed that the uncertainties involved are not very large and that the kinetic parameters of the single droplet experiments remain valid. This conclusion is supported by laboratory spray drying experiments.
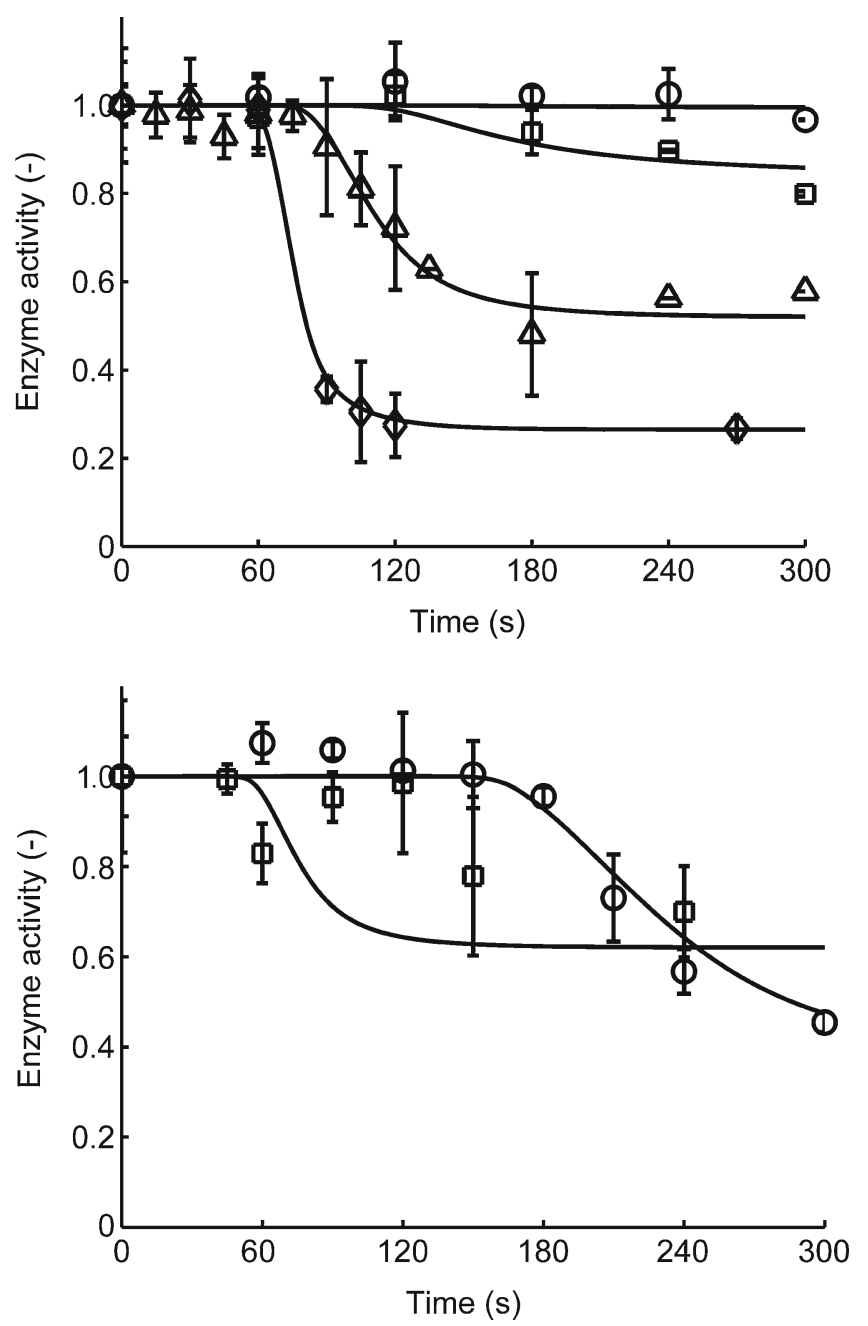

Fig. 6 Top the fitted residual enzyme activity obtained from single droplet drying experiments at varying air temperatures of $80^{\circ} \mathrm{C}$ (empty circles), $87^{\circ} \mathrm{C}$ (empty squares), $95^{\circ} \mathrm{C}$ (empty triangles) and $110^{\circ} \mathrm{C}$ (empty diamonds) for an initial droplet diameter of $800 \mu \mathrm{m}$. Bottom the residual enzyme activity predicted using the inactivation kinetics
In Fig. 6 (bottom), the effect of the initial droplet diameter on the residual $\beta$-galactosidase activity after drying is shown. The figure shows that the model accurately predicts the experimental data. Therefore, it can be concluded that although the values for the parameters in the model for inactivation kinetics obtained from the drying experiments may be less precise, the inactivation kinetics are accurate enough to predict the effect of drying on the inactivation of the enzyme. This is because the critical drying period dictates the end product properties.

Table 2 shows that the values of the confidence intervals of the parameters are smaller for the onestep inactivation compared to the two-step inactivation model. Therefore, it may be concluded that the onestep inactivation model is more favourable than the two-step inactivation model to describe the effect of
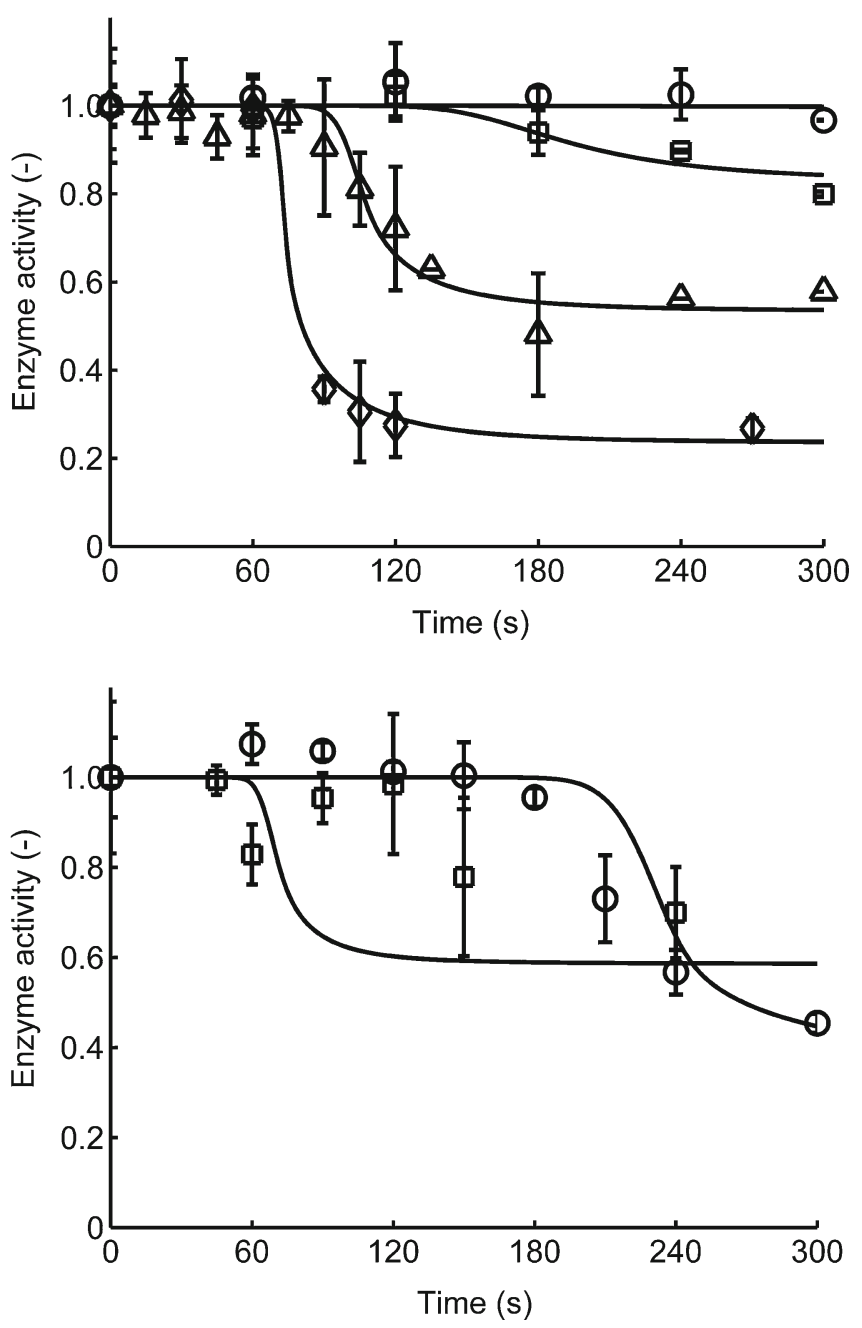

extracted from drying data at various heating air temperatures compared to the drying results from different initial droplet diameter: $500 \mu \mathrm{m}$ (empty squares) and 1,400 $\mu \mathrm{m}$ (empty circles). The $\beta$ galactosidase inactivation is described by the two-step inactivation model (left) and the one-step inactivation model (right) 
drying on enzyme activity loss. From practical point of view, the one-step inactivation model may be sufficient to translate the measured inactivation from single droplet experiments into useful inactivation kinetics.

\section{Laboratory-Scale Spray Drying}

The models were also applied to predict the residual enzyme activity after drying on a laboratory-scale spray dryer. The results are shown in Fig. 7. These results indicate that at an outlet air temperature below $100{ }^{\circ} \mathrm{C}$, the enzyme is hardly inactivated upon drying, while with an outlet air temperature higher than $100{ }^{\circ} \mathrm{C}$, the enzyme is increasingly inactivated with higher temperature as also observed by Yamamoto and Sano (1992).

The volume-weighted mean diameter $\left(d_{4,3}\right)$ of the spraydried particle is $6.94 \mu \mathrm{m}$, fed into the drying model to predict the residual enzyme activity. By assuming that the volumetric droplet shrinkage is equal to the amount of water removed, the initial droplet diameter was estimated at $11.8 \mu \mathrm{m}$ (initial moisture content $80 \% \mathrm{w} / \mathrm{w}$, Langrish 2009).

The model can predict the drying results reasonably accurate, but at temperatures between 100 and $120^{\circ} \mathrm{C}$, the predicted value of the residual activity of $\beta$-galactosidase is slightly lower than the experimental results. This may be due to the lower initial droplet size in reality due to nonideal shrinkage leading to more rapid drying and thus lower inactivation (see also Fig. 3).

Furthermore, Fig. 7 shows that there is only a small difference between the two inactivation models at temperatures larger than $100{ }^{\circ} \mathrm{C}$. This is probably because the inactiva- tion kinetic constant of the one-step inactivation model increases more quickly with temperature. This may lead to an overestimation of the inactivation kinetic constant at high temperatures.

\section{Conclusions}

A newly developed, small-scale experimental setup to mimic spray drying was presented which involves the drying of single droplets deposited on a hydrophobic flat plate. This approach ensures rapid and inexpensive trials while maintaining key parameters similar to the process condition on spray drying. In this study, the setup is used to evaluate the inactivation of $\beta$-galactosidase during drying.

To describe the physical and chemical changes during drying, a model based on heat and mass transfer is presented. The model, combined with the inactivation kinetics of $\beta$-galactosidase from separate heating experiments, was used to predict the loss in enzyme activity after drying. It is found that the model can provide a reasonably accurate prediction on the residual enzyme activity.

It was also shown that the inactivation kinetics of $\beta$ galactosidase can be directly extracted from the single droplets drying experiments rather than using the kinetics from separate heating experiments. The parameters that were obtained in this way were used to predict other experimental results both from other single droplet drying experiments and from a laboratory-scale spray dryer. The new inactivation kinetics provides reasonably accurate prediction on the residual enzyme activity for both procedures.

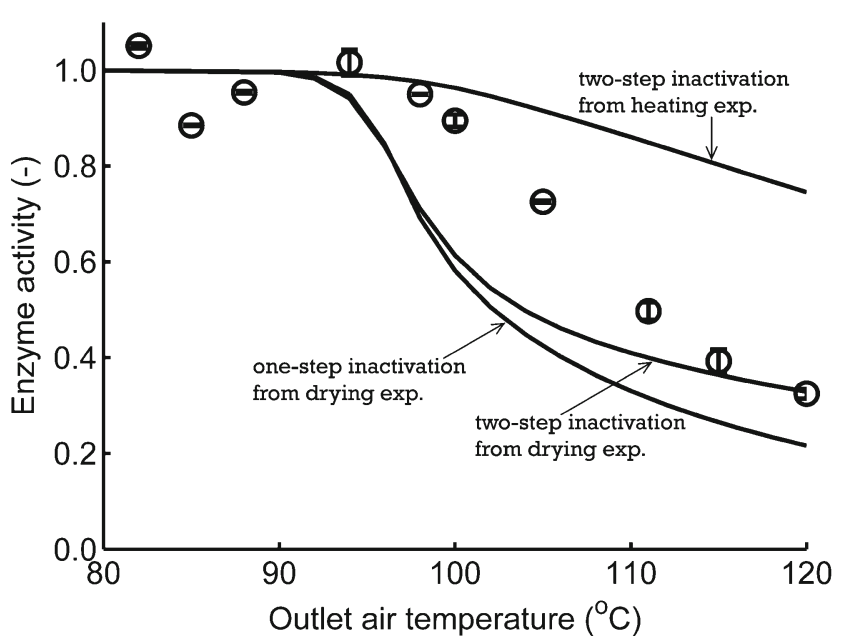

Fig. 7 Left the residual activity of $\beta$-galactosidase after spray drying in a laboratory-scale spray dryer. The symbols represent the experimental results at an inlet air temperature of $180^{\circ} \mathrm{C}$ and varied outlet air temperature. The lines represent the predicted enzyme activity using

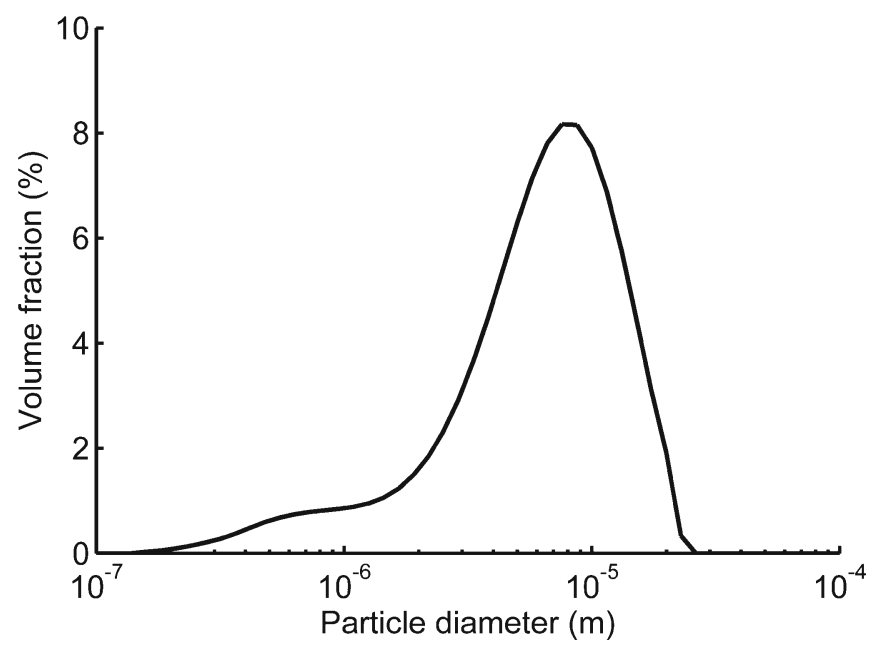

the inactivation kinetics obtained from the single droplet drying experiments and from the constant heating experiments. Right the particle size distribution of the powder obtained from the laboratory-scale spray dryer 
Nomenclature

\begin{tabular}{ll}
\hline$A$ & Area \\
$a_{\mathrm{w}}$ & Water activity \\
$c_{\mathrm{p}}$ & Heat capacity \\
$C$ & Concentration \\
$C_{\mathrm{g}}$ & Constant in GAB sorption model \\
$d$ & Diameter (2 $R_{\mathrm{d}}$ ) \\
$D$ & Diffusion coefficient \\
$E_{\mathrm{a}}$ & Arrhenius-type diffusion \\
& activation energy \\
$f$ & Parameter to describe the \\
& effect of moisture content \\
& on conformational \\
& stability of the enzyme \\
$g$ & Parameter to describe the effect \\
& of moisture content on the \\
& irreversible inactivation \\
& (second step) kinetic \\
& constant of the enzyme \\
$\mathrm{h}$ & Planck's constant \\
& (6.626 $\times 10^{-34}$ ) \\
$h$ & Convective heat \\
& transfer coefficient \\
& Enthalpy of evaporation
\end{tabular}

$\mathrm{m}^{2}$
-
$\mathrm{J} \mathrm{kg}^{-1} \mathrm{~K}^{-1}$
$\mathrm{~kg} \mathrm{~m}^{-3}$
-
$\mathrm{m}$
$\mathrm{m}^{2} \mathrm{~s}^{-1}$

$\mathrm{J} \mathrm{mol}^{-1}$$$
-
$$$$
\mathrm{J} \mathrm{s}^{-1}
$$$$
\mathrm{J} \mathrm{s}^{-1} \mathrm{~m}^{-2} \mathrm{~K}^{-1}
$$$$
\mathrm{J} \mathrm{kg}^{-1}
$$$$
\mathrm{J} \mathrm{mol}^{-1}
$$$$
\mathrm{J} \mathrm{mol}^{-1}
$$$$
\mathrm{kg} \mathrm{s}^{-1}
$$$$
\mathrm{J} \mathrm{K}^{-1}
$$$$
\mathrm{s}^{-1}
$$$$
\mathrm{s}^{-1}
$$$$
\mathrm{m} \mathrm{s}^{-1}
$$$$
\text { Mass transfer coefficient }
$$$$
K_{\mathrm{g}} \quad \text { Constant in GAB sorption model }
$$$$
K_{1} \quad \text { Unfolding equilibrium constant }
$$$$
\text { of } \beta \text {-galactosidase }
$$$$
L
$$$$
m
$$$$
m_{\mathrm{u}}
$$$$
M_{\mathrm{w}}
$$$$
n
$$$$
p
$$$$
p_{i}
$$

$$
\text { Length }
$$

Mass

Parameter to describe the effect of moisture content on unfolding equilibrium of $\beta$-galactosidase

Molecular weight of water $\left(18 \cdot 10^{-3}\right)$

Number of partition

Uncertainty of the parameters

Parameter to describe the effect of moisture content on irreversible complete denaturation rate constant of $\beta$-galactosidase

Pressure

Prandtl number

Heat

Distance in radial coordinate
Nomenclature

\begin{tabular}{|c|c|c|}
\hline$R$ & Ideal gas constant (8.314) & $\mathrm{J} \mathrm{mol}^{-1} \mathrm{~K}^{-1}$ \\
\hline $\operatorname{Re}$ & Reynolds number & - \\
\hline$R_{\mathrm{d}}$ & Droplet radius & $\mathrm{m}$ \\
\hline$\Delta S^{\ddagger}$ & Activation entropy & $\mathrm{J} \mathrm{mol}^{-1} \mathrm{~K}^{-1}$ \\
\hline$\Delta \Delta S^{+}$ & $\begin{array}{l}\text { Activation entropy difference } \\
\text { between unfolding and } \\
\text { refolding reaction }\end{array}$ & $\mathrm{J} \mathrm{mol}^{-1} \mathrm{~K}^{-1}$ \\
\hline $\mathrm{Sc}$ & Schmidt number & - \\
\hline$t$ & Time & s \\
\hline$T$ & Temperature & ${ }^{\circ} \mathrm{C}$ \\
\hline$u$ & Velocity & $\mathrm{m} \mathrm{s}^{-1}$ \\
\hline V & Volume & $\mathrm{m}^{3}$ \\
\hline$x$ & Distance in Cartesian coordinate & $\mathrm{m}$ \\
\hline$x_{\mathrm{w}}$ & Mass fraction of water & $\mathrm{kg} \mathrm{kg}^{-1}$ \\
\hline$X_{\mathrm{w}}$ & Moisture content & $\mathrm{kg} \mathrm{kg}^{-1}$ dry matter \\
\hline$X_{\mathrm{wm}}$ & $\begin{array}{l}\text { Monolayer moisture content in } \\
\text { GAB sorption model }\end{array}$ & $\mathrm{kg} \mathrm{kg}^{-1}$ dry matter \\
\hline$y$ & Distance in Cartesian coordinate & $\mathrm{m}$ \\
\hline$z$ & Distance in Cartesian coordinate & $\mathrm{m}$ \\
\hline$Z$ & Thickness & $\mathrm{m}$ \\
\hline
\end{tabular}

Greek symbols

\begin{tabular}{|c|c|c|}
\hline$\delta$ & $\begin{array}{l}\text { Hydrodynamic boundary } \\
\text { layer thickness }\end{array}$ & $\mathrm{m}$ \\
\hline$\delta_{\mathrm{t}}$ & $\begin{array}{l}\text { Thermal boundary } \\
\text { layer thickness }\end{array}$ & $\mathrm{m}$ \\
\hline$\lambda$ & Thermal conductivity & $\mathrm{J} \mathrm{s}^{-1} \mathrm{~m}^{-1} \mathrm{~K}^{-1}$ \\
\hline$\mu$ & Dynamic viscosity & $\mathrm{Pa} \mathrm{s}$ \\
\hline$\rho$ & Density & $\mathrm{kg} \mathrm{m}^{-3}$ \\
\hline$v$ & Kinematic viscosity & $\mathrm{m}^{2} \mathrm{~s}^{-1}$ \\
\hline \multicolumn{3}{|c|}{ Subscript } \\
\hline $\mathrm{a}$ & Air & \\
\hline avg & Average & \\
\hline cond & Conduction & \\
\hline $\mathrm{d}$ & Droplet & \\
\hline int & Intercept & \\
\hline $\mathrm{m}$ & Very dry matrix & \\
\hline obs & Observed & \\
\hline $\mathrm{p}$ & $\begin{array}{l}\text { Flat plate for } \\
\text { droplet deposition }\end{array}$ & \\
\hline ref & Reference & \\
\hline $\mathrm{s}$ & Solute & \\
\hline sat & Saturated & \\
\hline $\mathrm{w}$ & Water & \\
\hline 0 & Initial & \\
\hline$\infty$ & Bulk air & \\
\hline
\end{tabular}

Acknowledgement The authors thank Advanced Chemical Technologies for Sustainability (ACTS)-Netherlands Organization for Scientific Research (NWO) for financial aid through Process on a Chip (PoaC) program.

Open Access This article is distributed under the terms of the Creative Commons Attribution Noncommercial License which permits any 
noncommercial use, distribution, and reproduction in any medium, provided the original author(s) and source are credited.

\section{References}

Adhikari, B., Howes, T., Bhandari, B. R., \& Truong, V. (2000). Experimental studies and kinetics of single drop drying and their relevance in drying of sugar-rich foods: A review. International Journal of Food Properties, 3(3), 323-351.

Ali Al Zaitone, B., \& Tropea, C. (2011). Evaporation of pure liquid droplets: Comparison of droplet evaporation in an acoustic field versus glass-filament. Chemical Engineering Science, 66(17), 3914-3921.

Bolz, R. E. \& Tuve, G. L. (1973). CRC handbook of tables for applied engineering science. CRC Press, Cleveland, Ohio, USA.

Chen, X. D., \& Patel, K. C. (2007). Micro-organism inactivation during drying of small droplets or thin-layer slabs - A critical review of existing kinetics models and an appraisal of the drying rate dependent model. Journal of Food Engineering, 82(1), 1-10.

Chuchottaworn, P., Fujinami, A., \& Asano, K. (1984). Experimental study of evaporation of a volatile pendant drop under high mass flux conditions. Journal of Chemical Engineering Japan, 17, 7-13.

Coumans, W. J. (2000). Models for drying kinetics based on drying curves of slabs. Chemical Engineering and Processing, 39(1), 53-68.

Crank, J. (1990). The mathematics of diffusion. London, UK: Oxford University Press.

Etzel, M. R., Suen, S. Y., Halverson, S. L., \& Budijono, S. (1996). Enzyme inactivation in a droplet forming a bubble during drying. Journal of Food Engineering, 27(1), 17-34.

Fang, Z., \& Bhandari, B. (2010). Encapsulation of polyphenols-A review. Trends in Food Science \& Technology, 21(10), 510-523.

Farid, M. (2003). A new approach to modelling of single droplet drying. Chemical Engineering Science, 58(13), 2985-2993.

Filková, I., Huang, L.X. \& Mujumdar, A. (2006). Industrial spray drying systems. In: Handbook of Industrial Drying, 3rd Ed. Boca Raton: CRC Press.

Gianfrancesco, A., Turchiuli, C., Flick, D., \& Dumoulin, E. (2010). CFD modeling and simulation of maltodextrin solutions spray drying to control stickiness. Food and Bioprocess Technology, 3 (6), 946-955.

Goff, J. A., \& Gratch, S. (1946). Low-pressure properties of water from 160 to 212 F, in Transactions of the American Society of heating and ventilating engineers. The $52^{\text {nd }}$ annual meeting of the American society of heating and ventilating engineers. New York: 95-122.

Goula, A. M., \& Adamopoulos, K. G. (2004). Influence of spray drying conditions on residue accumulation-simulation using CFD. Drying Technology, 22(5), 1107-1128.

Incropera, F. P., \& De Witt, D. P. (1985). Fundamentals of heat and mass transfer (2nd ed.). New York: Wiley.

Kakac, S., \& Yener, Y. (1993). Heat conduction. Washington: Taylor \& Francis.

Langrish, T. (2009). Degradation of vitamin C in spray dryers and temperature and moisture content profiles in these dryers. Food and Bioprocess Technology, 2(4), 400-408.

Li, X., Anton, N., Arpagaus, C., Belleteix, F., \& Vandamme, T. F. (2010). Nanoparticles by spray drying using innovative new technology: The Büchi Nano Spray Dryer B-90. Journal of Controlled Release, 147(2), 304-310.

Luyben, K. C. A. M., Liou, J. K., \& Bruin, S. (1982). Enzyme degradation during drying. Biotechnology and Bioengineering, 24(3), 533-552.

Meerdink, G., \& van't Riet, K. (1991). Inactivation of thermostable [alpha]-amylase during drying. Journal of Food Engineering, 14 (2), 83-102.
Mezhericher, M., Levy, A., \& Borde, I. (2008). Heat and mass transfer of single droplet/wet particle drying. Chemical Engineering Science, 63(1), 12-23.

Millqvist-Fureby, A., Malmsten, M., \& Bergenståhl, B. (1999). Spraydrying of trypsin - surface characterisation and activity preservation. International Journal of Pharmaceutics, 188(2), 243-253.

Mosaad, M. (1999). Laminar forced convection conjugate heat transfer over a flat plate. Heat and Mass Transfer, 35(5), 371-375.

Peighambardoust, S. H., Golshan Tafti, A., \& Hesari, J. (2011). Application of spray drying for preservation of lactic acid starter cultures: A review. Trends in Food Science \& Technology, 22(5), 215-224.

Perdana, J., Fox, M. B., Schutyser, M. A. I., \& Boom, R. M. (2011a). Single-droplet experimentation on spray drying: Evaporation of a sessile droplet. Chemical Engineering and Technology, 34(7), 1151-1158.

Perdana, J., Fox, M. B., Schutyser, M. A. I. \& Boom, R. M. (2011b). Enzyme inactivation kinetics: Coupled effects of temperature and moisture content. Food Chemistry (in press).

Quirijns, E. J., Boxtel, A. J. B., Loon, W. K. P., \& Straten, G. (2005). Sorption isotherms, GAB parameters and isosteric heat of sorption. Journal of the Science of Food and Agriculture, 85(11), $1805-1814$.

Ranz, W. E., \& Marshall, J. M. (1952). Evaporation from drops, Part II. Chem. Eng. Prog., 48(3), 141-146 (Part I); 48(4), 173-1 80 \{Part II).

Räderer, M., Besson, A., \& Sommer, K. (2002). A thin film dryer approach for the determination of water diffusion coefficients in viscous products. Chemical Engineering Journal, 86(1-2), 185-191.

Ré, M. I. (1998). Microencapsulation by spray drying. Drying Technology: An International Journal, 16(6), 1195-1236.

Richard, C., Aster, B. B. \& Clifford, H. T. (2005). Appendix C. Review of vector calculus. In: International Geophysics, pp. 273-280. New York: Academic Press.

Sansone, F., Mencherini, T., Picerno, P., d'Amore, M., Aquino, R. P., \& Lauro, M. R. (2011). Maltodextrin/pectin microparticles by spray drying as carrier for nutraceutical extracts. Journal of Food Engineering, 105(3), 468-476.

Schiffter, H., \& Lee, G. (2007). Single-droplet evaporation kinetics and particle formation in an acoustic levitator. Part 1: Evaporation of water microdroplets assessed using boundary-layer and acoustic levitation theories. Journal of Pharmaceutical Sciences, 96(9), 2274-2283.

Schlichting, H., \& Gersten, K. (2000). Boundary-layer theory (8th ed.). Berlin: Spinger.

Seber, G. A. F. \& Wild, C. J. (2005). Computational methods for nonlinear least squares. In: Nonlinear regression, pp. 619-660. New York: Wiley.

Sloth, J., Kiil, S., Jensen, A. D., Andersen, S. K., Jørgensen, K., Schiffter, H., \& Lee, G. (2006). Model based analysis of the drying of a single solution droplet in an ultrasonic levitator. Chemical Engineering Science, 61(8), 2701-2709.

Straatsma, H., Verschueren, M., Gunsing, M., Verdurmen, R. \& Jong, P. d. (2007). CFD simulation of spray drying of food products. In: Computational fluid dynamics in food processing, pp. 249-286. New York: CRC Press.

Thirumaleshwar, M. (2009). Fundamentals of heat and mass transfer. New Delhi: Dorling Kindersley.

Vehring, R., Foss, W. R., \& Lechuga-Ballesteros, D. (2007). Particle formation in spray drying. Journal of Aerosol Science, 38(7), 728-746.

Walton, D. E., \& Mumford, C. J. (1999). The morphology of spraydried particles: The effect of process variables upon the morphology of spray-dried particles. Chemical Engineering Research and Design, 77(5), 442-460.

Wijlhuizen, A. E., Kerkhof, P. J. A. M., \& Bruin, S. (1979). Theoretical study of the inactivation of phosphatase during spray drying of skim-milk. Chemical Engineering Science, 34(5), 651-660. 
Wu, W. D., Lin, S. X., \& Chen, X. D. (2011). Monodisperse droplet formation through a continuous jet break-up using glass nozzles operated with piezoelectric pulsation. AICHE Journal, 57(6), $1386-1392$.

Xin Huang, L., Filkova, I. \& Mujumdar, A. (2006). Industrial spray drying systems. In: Handbook of industrial drying, 3rd ed. New York: CRC Press.
Yamamoto, S., \& Sano, Y. (1992). Drying of enzymes: enzyme retention during drying of a single droplet. Chemical Engineering Science, 47(1), 177-183.

Yoshioka, S., Aso, Y., Izutsu, K-i, \& Kojima, S. (1994). Is stability prediction possible for protein drugs? Denaturation kinetics of $\beta$ galactosidase in solution. Pharmaceutical Research, 11(12), $1721-1725$. 